International Journal of Instruction e-ISSN: 1308-1470 • www.e-iji.net

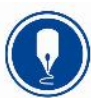

January $2019 \bullet$ Vol.12, No.1

p-ISSN: 1694-609X

pp. 1517-1532

Received: 10/10/2018

Revision: 01/12/2018

Accepted: 04/12/2018

OnlineFirst: 16/12/2018

\title{
The Analysis of the Problems Posed by Pre-service Elementary Teachers for the Addition of Fractions
}

\author{
Sumeyra Dogan-Coskun \\ Dr., Eskisehir Osmangazi University, Turkey, s-dogan@ogu.edu.tr
}

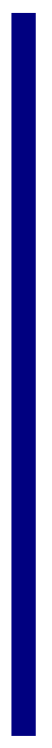

\begin{abstract}
The purpose of this study is to analyze pre-service elementary teachers' problems in terms of the different meanings of the addition of fractions and to determine the types of errors made in these problems. Data were collected from 83 pre-service elementary teachers in the spring semester of the 2016-2017 academic year by means of a problem posing test related to the addition of fractions. The problem posing test consisted of four questions asking pre-service elementary teachers to pose a problem corresponding to fractions given in a symbolic form. After the problems posed by pre-service elementary teachers were categorized as a problem, not-a-problem, or unable to pose a problem via content analysis method, the meanings, part-part-whole and joining, incorporated into these problems were analyzed. Finally, the types of errors made in these problems were classified. The analysis of the posed problems indicated that although most of the pre-service elementary teachers were able to pose problems, less than one-fourth of these problems were appropriate for the given symbolic form of the addition of fractions. The subsequent meaning analysis of the problems revealed that pre-service elementary teachers were more successful in posing part-part-whole problems than in posing join problems. In terms of error types, the majority of pre-service elementary teachers made the error of failure in establishing part-whole relationship.
\end{abstract}

Keywords: fractions, problem posing, error types, pre-service elementary teachers, teacher education

\section{INTRODUCTION}

Since an understanding of fractions is accepted as necessary for students' future success in mathematics achievement, fractions are one of the topics introduced in the first grade and then extended throughout the elementary school mathematics curriculum of Turkey and other countries (Ministry of National Education [MoNE], 2018; National Council of Teachers of Mathematics [NCTM], 2000). In order to emphasize its importance, The National Mathematics Advisory Panel [NMAP] (2008) explains that an understanding

Citation: Dogan-Coskun, S. (2019). The Analysis of the Problems Posed by Pre-service Elementary Teachers for the Addition of Fractions. International Journal of Instruction, 12(1), 1517-1532. https://doi.org/10.29333/iji.2019.12197a 
of fractions is essential for students' performance in other math topics and that "such proficiency is foundational for algebra" (p. xvii). However, in spite of its importance, fractions are one of the topics that most elementary school students struggle with (Isiksal, 2006; Newton, 2008). Moss and Case (1999) explain that this struggle results from devoting too much time to teaching arithmetic procedures. As it is anticipated, teachers need to engage their students in meaningful activities to help them meaningfully learn the content. That is, presenting the arithmetic procedures or explaining each step in detail does not guarantee that students will learn the content conceptually. Otherwise, the students perform these procedures without knowing the reasons behind them.

Another difficulty of the students entails confusion between fractions and natural numbers such that students try to use their previous natural number knowledge for their new knowledge of fractions. They see fractions as two discrete numbers separated by a horizontal bar rather than a single number (Ni \& Zhou, 2005). Although teachers are aware of their students' misconceptions and difficulties regarding fractions, teachers do not know how to overcome these troubles or to contribute to students' conceptual understanding of fractions (Lamon, 2012). Teachers also see fractions as a difficult topic both to understand and to teach (Smith, 2002). Accordingly, some researchers assert that if teachers engage in problem posing and solving activities, they will be more aware of their limitations and can take necessary precautions to improve their ability to pose and solve problems (Ticha' \& Hošpesova', 2009). A teacher's ability to pose and solve problems is critical as it affects their students' understanding and learning of mathematics (Stoyanova, 2003). Similarly, Olson and Knott (2013) emphasize that a teacher's problem posing ability is critical as s/he helps students to become better and meaningful problem posers themselves. Otherwise, students tend to pose similar problems just by changing the numbers given or told by their teachers (Dubé \& Robinson, 2010). Crespo and Sinclair (2008) explain that although problem posing can be used as an effective teaching method, little is known about what pre-service teachers find difficult in its application. The Conference Board of Mathematical Sciences [CBMS] (2001) also explains that more importance should be placed on preparing preservice teachers who are poorly prepared to teach mathematics by examining what they know. In this respect, the purpose of this study is to examine the problems posed and the errors made by pre-service elementary teachers for the addition of fractions.

\section{Problem Posing}

"Do we have to pose problems?" or "Why do we have to pose problems?" are some of the questions that should be answered. In fact, the NCTM (1989) first answered these questions by stating that problem posing is "at the heart of doing mathematics" (p. 138). Then, in 1991 the NCTM stated that "students should be given opportunities to formulate problems from given situations and create new problems by modifying the conditions of a given problem" (p. 95). Since that time, many researchers have accepted problem posing as an important feature of mathematics classrooms (Brown \& Walter, 1993; 2005; Kilpatrick, 1987; Silver, 1994; Stoyanova, 2003). Specifically, Brown and Walter (1993) explain that problem posing helps students understand their thinking, learn from their friends, and comprehend the nature of mathematics. In another study, 
Brown and Walter (2005) explain that problem posing not only makes students create new ideas but acquire these ideas with a deeper understanding. Furthermore, Silver (1994) asserts that students make sense of their worlds by means of problem posing activities. In addition to the above-mentioned benefits, problem posing activities enhance students' creativity, reasoning, and reflection (Bonotto, 2013; Cunningham, 2004). In another study, Bonotto (2009) asserts that problem posing activities prepare students to cope with other problems that they can face in their daily lives. Problem posing is also important for teachers as it allows them to understand what their students think or what kind of misconceptions or difficulties their students have (Silver, 1994). To overcome these troubles and enhance students' understanding, problem posing can be used as avenue (Barlow \& Drake, 2008). Therefore, teachers need to allow their students to pose problems to strengthen their mathematics instruction.

Although there is agreement on the importance of problem posing, this importance has been defined in different ways throughout existing literature, including problem posing, problem formulation, and problem generation (Brown \& Walter, 1993; Kilpatrick, 1987; Silver, 1994), and different problem posing frameworks have been used in previous studies (Christou, Mousoulides, Pittalis, Pitta-Pantazi, \& Sriraman, 2005; Silver, 1994; Stoyanova, 1995). While Kilpatrick (1987) uses the term "problem formulation" to explain when some parts of the given problem are changed, Brown and Walter (1993) refer to "problem posing" as when a new problem is generated from the given situation. On the other hand, Silver (1994) uses the term "problem generation" to include "both the generation of new problems and the re-formulation, of given problems" (p. 19). Singer, Ellerton, and Cai's (2013) explain that although the terms "formulating", "generating", and "posing problems" are not new, the differences among these definitions will remain and researchers will use the above-mentioned terms interchangeably. In this paper, the term "problem posing" will be used, and it will be defined as a new problem written that shows the meaning of addition of fractions.

Similar to the different definitions of problem posing, researchers have been using different problem posing frameworks in their research (Christou et al., 2005; Silver, 1994; Stoyanova, 1995). One of these frameworks, Stoyanova's framework (1995), distinguishes problem posing as free, semi-structured, and structured. According to her explanation, problem posing is free when students are asked to pose a problem without any limitation. When students are given an open situation with a structure to explore and are asked to complete it by using their previous mathematical knowledge, it is semistructured problem posing. While giving some information such as "I have 10 pencils and my friend has 4 erasers" and asking students to write as many problems as possible using the information is an example of free problem posing, providing students with an operation such as " $10+5=$ ?" is an example of semi-structured problem posing. In structured problem posing situations, students are asked to generate a new problem taking its solution into account or to present the problem in a different way. This study prefers to use problem posing as a term, similar to Brown and Walter (1993), and use Stoyanova's framework (1995) to distinguish problem posing situations as free, semistructured, and structured. More specifically, in the present study, semi-structured 
problems posed for the addition of fractions and errors made in these problems by preservice elementary teachers are examined.

\section{Fractions}

The NMAP (2008) emphasizes that teachers need to do their best to make their students comprehend certain key mathematics topics such as fractions. Comprehending fractions is not only essential for success in mathematics, but also essential for success in a wide range of occupations such as doctor, engineer, and pharmacist (Davidson, 2012). However, fractions will continue to be regarded as a difficult topic and students will not be ready for topics taught in their future years (Newton, 2008). Specifically, Van de Walle, Karp, and Bay-Williams (2016) assert that a conceptual understanding of fractions will help students to understand more abstract topics such as algebra, geometry and so on. However, understanding fractions is more than learning algorithms and implementing these algorithms successfully.

In order to be successful in the above-mentioned topics, students should know the different meanings of fractions, namely part-whole, measure, quotient, operator, and ratio (Van de Walle et al., 2016). The first meaning of fractions, part-whole, is about "a number of equal parts of a unit out of the total number of equal parts into which the unit is divided" (Lamon, 2012, p. 145). Furthermore, Lamon (2012) states that since the part-whole meaning of fractions can be easily modelled or explained by means of materials used in daily life, such as apples, cookies, and pizzas, it allows students to understand fractions easily. Although the part-whole meaning of fractions is fundamental for the other meanings of fractions, too much focus on the part-whole meaning by means of examples or activities involving shading regions of different shapes limits students' understanding of fractions ( $\mathrm{Wu}, 2008)$. That is, emphasizing that parts must be equal or correctly counting the shaded parts is not enough to understand fractions (Van de Walle et al., 2016). In order to overcome these limitations, teachers should make their students define the unit fraction in addition to defining the part or whole (Beckmann, 2005). Another meaning of fractions, measure, focuses on the concept of the unit fraction as a relationship between the quantity being measured and the unit being measured. Understanding the unit is important as a fraction represents different quantities depending on the unit, such that $3 / 4$ can represent both three $1 / 4$ units or one $3 / 4$ unit. If a relationship between the number of the object(s) being shared and the number of sharers is the focus of an example or a problem, then the example or problem is referring to the quotient meaning of fractions. The quotient meaning of fractions is important in making students understand that a fraction does not consist of two separate numbers. Instead, it is the result of the division of these two numbers (Bottge, Ma, Gassaway, Butler, \& Toland, 2014). For example, dividing 5 cakes among 6 people and finding $5 / 6$ as the amount of cake eaten by each person refers to the quotient meaning of fractions. Another and the most difficult of these meanings, operator, requires multiplicative reasoning as it operates as a function to enlarge or shrink a quantity. The final meaning, ratio, is a multiplicative relationship between two quantities (Lamon, 2012). Considering the above-mentioned explanations, the following examples can be given to make these meanings clear for the fraction one-fourth: 
- Part-whole: One pizza cut into four equal pieces

- Measure: 1 boy with glasses and 4 girls with glasses. The number of boy with glasses is $1 / 4$ of the number of girls with glasses.

- Quotient: Two pizzas equally shared by eight children, so each child gets $1 / 4$ of pizza.

- Operator: $1 / 4$ of 8 pizza slices is 2 pizza slices.

- Ratio: One of every four children is a girl.

Since most curricula do not adequately explain the above-mentioned meanings of fractions, students can have troubles in comprehending fractions (Charalambous \& PittaPantazi, 2007). However, all of these meanings come into play when students begin to learn operations involving fractions. Hence, comprehending all five meanings of fractions helps students to both solve the problems related to the operations with fractions and understand the reasons behind the procedures used to solve them.

Addition of fractions, one of the operations of fractions, has the same meanings as they do with natural numbers such that problems for the addition of fractions involve partpart-whole and join problems (Cathcart, Pothier, Vance, \& Bezuk, 2003). Although the addition of fractions is accepted as the easiest operations of fractions, students have difficulties resulting from their natural number knowledge. For example, when adding fractions, students think that numerators and denominators can be treated as separate natural numbers, and the result can be written as $2 / 4$ for $(1 / 2+1 / 2)$ (Newton, Willard, \& Teufel, 2014). Understanding the relationship between a numerator and a denominator is important as it allows students to accept fractions as quantities (Petit, Laird, Marsden, \& Ebby, 2015). Otherwise, they will not be able to understand two fractions with unlike denominators are represented with different units and will also have troubles with the task of adding fractions with unlike denominators. Furthermore, they will think that only the numerators are used and denominators stay the same in the addition of fractions (Siegler \& Pyke, 2013). At this point, problem posing activities may help teachers gain insight into their students' understanding and misconceptions of the addition of fractions (Kontorovich, Koichu, Leikin, \& Berman, 2012). To be able to determine what the students know and what kind of errors made in their posed problems, teachers need to pose correct problems themselves. In spite of its importance, in-service and pre-service teachers have difficulties in problem posing activities related to the fractions (Isik \& Kar, 2012; Isiksal, 2006; Kilic, 2015; Rizvi, 2004; Rizvi \& Lawson, 2007; Tichá \& Hošpesová, 2012). Specifically, Isik and Kar (2012) stated that pre-service teachers made different type of errors when they were asked to pose problems related to the division of fractions. As the purpose of this study is to examine pre-service elementary teachers' posed problems related to the addition of fractions, it can be seen that whether the above finding is specific to the division of fractions or is also valid for the addition of fractions. That is, although teachers are able to solve an algorithmic expression of fractions, the addition of fractions in this study, they may not be able to pose an appropriate problem for the given expression showing weakness of their knowledge of fractions. To address this problem, one of the purposes of this study is to analyze the appropriateness of pre-service elementary teachers' problems in terms of the different meanings of the addition of fractions. When pre-service teachers were given two 
fractions such as $1 / 2$ and $3 / 4$ and were asked to pose problems, most of them posed problems related to the addition of fractions (Kilic, 2015). However, the appropriateness of these problems and the type of errors made in these problems were not considered. Therefore, investigating the posed problems related to addition of fractions by focusing on the errors would contribute to the related literature. Determining these errors is important as it may be conveyed to students (Moseley, Okamoto, \& Ishida, 2007). Furthermore, there are studies that show that experience in problem posing activities enhances problem posing abilities (Crespo \& Sinclair, 2008; Toluk-Ucar, 2009). In order to help teachers improve their abilities, and hence their students' abilities, the first thing that should be done is to know their difficulties when doing so. By identifying the errors made in the posed problems and the difficulties encountered when posing problems, important implications to inform teacher educators to design their courses in such a way that they are given enough opportunities to pose, share, and critique problems will be suggested. Considering that elementary education is one of the most important parts of a person's educational life and may be the most important driver affecting his/her educational success as a whole, how elementary teachers and their abilities play a vital role can be understood. That is, the findings of this study would offer promising routes for further studies. In this context, the present study seeks to answer the following research questions:

o What meanings, including part-part-whole and joining, do pre-service elementary school teachers incorporate into the problems that they pose for the addition of fractions?

o What are the different types of errors in the problems posed for the addition of fractions by pre-service elementary teachers?

\section{METHOD}

\section{Participants}

In Turkey, elementary teachers who are educated to teach mathematics from first grade through fourth grade follow a four-year bachelor degree in faculty of education. Prior to entering an elementary education program, pre-service teachers must pass the national university entrance exam. The elementary education program involves courses on general knowledge related to art, music, mathematics, Turkish language, science, and social sciences, as well as on the pedagogy of these courses. Specifically, the program offers pre-service elementary teachers two content courses about mathematics in their first year and two teaching courses about mathematics in their third year. While the former two of these courses focus on fundamental elementary mathematical concepts and their development, the latter two focus on instructional methods and strategies for teaching these fundamental mathematical concepts of elementary school mathematics. The participants of this study were a convenience sample of 83 pre-service elementary teachers in three different sections of methods of teaching mathematics course during the spring semester of the 2016-2017 academic year at a public university in Turkey. During the data collection process, pre-service elementary teachers had already taken their mathematics content courses and the first of the methods of teaching mathematics courses and were taking the second of the methods of teaching mathematics courses. 
Before conducting the study, all pre-service elementary teachers enrolled in this course were given information about the study and were invited to participate. Furthermore, they were notified that their answers would be used for research purposes only and would be kept confidential. Each participant was assigned a code by the researcher, such as PT1, PT2, PT3, ...PT83.

\section{Data Collection}

The main source of data was a four question Problem Posing Test (PPT) related to the addition of fractions. These questions asked pre-service elementary teachers to pose a problem corresponding to the fractions given in symbolic form. Pre-service elementary teachers were asked to pose a problem for each symbolic form in the PPT immediately after being taught fractions and the teaching of them, and the completion of the PPT lasted one lesson hour (approximately 40 minutes). Items in the PPT are given in Table 1 below.

Table 1

Questions in the PPT

\begin{tabular}{ll} 
Write a story problem for $\frac{1}{4}+\frac{3}{4}=?$ & $\begin{array}{l}\text { Addition of proper fractions where the sum is proper } \\
\text { fraction }\end{array}$ \\
\hline Write a story problem for $\frac{1}{3}+\frac{1}{2}=?$ & $\begin{array}{l}\text { Addition of proper fractions where the sum is proper } \\
\text { fraction }\end{array}$ \\
\hline Write a story problem for $\frac{4}{6}+\frac{3}{6}=?$ & $\begin{array}{l}\text { Addition of proper fractions where the sum is a mixed } \\
\text { fraction }\end{array}$ \\
\hline Write a story problem for $\frac{1}{3}+\frac{5}{6}=?$ & $\begin{array}{l}\text { Addition of proper fractions where the sum is a mixed } \\
\text { fraction }\end{array}$
\end{tabular}

\section{Data Analysis}

Pre-service elementary teachers' answers to the questions in the PPT were analyzed via categorical analysis, one of the techniques of the content analysis method. Their answers were initially categorized as problem, not-a-problem, or unable to pose a problem, similar to previous studies (Isik \& Kar, 2012). If pre-service teachers' answers were categorized as problem, their answers were reexamined in an attempt to identify the meanings of the addition of fractions. Specifically, the meanings were categorized into "part-part-whole", "join", and "others" if a word problem was written by the pre-service teachers. While the categories of part-part-whole and join refer to the problems written for the addition of fractions, the category of others refers to the problems written for the operations of fractions other than the addition of fractions. Then, the type of errors in their posed problems was determined according to the error categories present in the literature (Isik \& Kar, 2012; Toluk-Ucar, 2009). Specifically, in this study, pre-service elementary teachers' posed problems for the last question in the PPT was analyzed. The errors made in the pre-service elementary teachers' answers for the story problem for $1 / 3+5 / 6=$ ? were classified as expressing the added second fraction over the remainder of whole (AE1), failure in expressing the operation in the question root (AE2), attributing natural number meaning to the result of the operation (AE3), confusing units (AE4), 
attributing natural number meaning to the added fractions (AE5), failure in establishing part-whole relationship (AE6), logical error (AE7), and attributing a value to the whole (AE8). The problems posed by the pre-service elementary teachers were reviewed carefully and coded by the author of the paper as well as a $\mathrm{PhD}$ student who had experience in problem posing studies using the above-mentioned error types. After coding their answers independently, the researchers' categorizations were compared and a $92 \%$ consistency level was achieved.

\section{FINDINGS}

The results of this study are presented in turn: the meanings of problems posed by the pre-service elementary teachers for the addition of fractions and the errors made in these problems.

\section{The Meanings of the Problems Posed for the Addition of Fractions}

To identify the meanings focused on in pre-service elementary teachers' story problems for the last question in the PPT, their posed problems were analyzed regardless of whether the problems were correct or not, and the meanings of them are presented in Table 2. That is, correctness of the posed problems was not considered; however, the meanings employed in the problems were examined.

Table 2

The distribution of meanings focused on in the last question of the PPT

\begin{tabular}{llllll}
\hline & \begin{tabular}{l} 
Problem \\
Part-Part- \\
\cline { 2 - 5 }
\end{tabular} & Join & Others & $\begin{array}{l}\text { Not a } \\
\text { Problem }\end{array}$ & $\begin{array}{l}\text { Unable } \\
\text { to Pose }\end{array}$ \\
\hline $\begin{array}{l}\text { Write a story problem } \\
\text { for } \frac{1}{3}+\frac{5}{6}=?\end{array}$ & 47 & 25 & 2 & 1 & $\mathrm{n}$ \\
\hline
\end{tabular}

As can be seen from Table 2, 72 of 83 pre-service elementary teachers posed a problem focusing either on part-part-whole meaning or joining meaning for the addition of fractions. Most of the pre-service elementary teachers focused on the part-part whole meaning of the addition operation. Figure 1 shows an example of appropriate posing of part-part-whole meaning. For Figure 1, the pre-service elementary teacher PT37 wrote: "A mom bought 2 cakes of the same size for her kids (Ayse and Ali). While Ayse divided the first cake into 3 equal pieces and ate 1 of these pieces, Ali divided the second cake into 6 equal pieces and ate 5 pieces of them. What fraction of the cake did they eat together?"

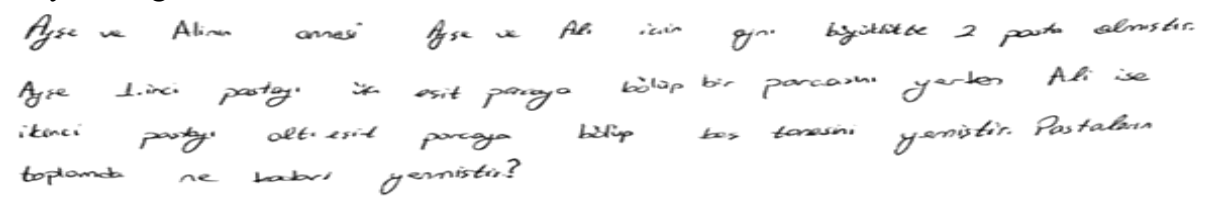

Figure 1

Appropriate Posing: Part-Part-Whole 
Twenty-five pre-service elementary teachers posed problems focusing on the joining meaning of the addition operation. Furthermore, of these pre-service elementary teachers who employed the joining meaning, only three of them posed an appropriate problem. One of these appropriate problems was given below:

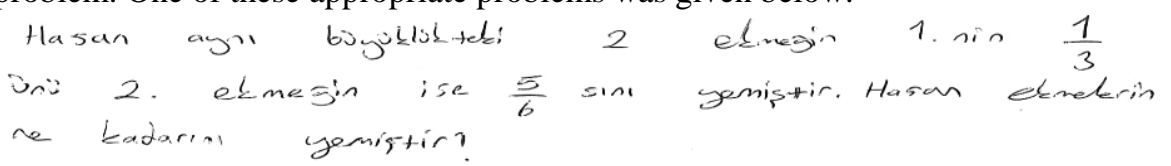

Figure 2

Appropriate Posing: Joining

PT59 wrote in Figure 2: "Hasan ate ate 1/3 of the first bread out of two same size breads and $5 / 6$ of the second bread out of two same size breads. What fraction of the breads did Hasan eat in total?" On the other hand, 8 pre-service elementary teachers were not able to pose a story problem for the addition of fractions and 2 pre-service elementary teachers posed a problem requiring an operation other than addition. Furthermore, one of the pre-service elementary teacher wrote "How much is the addition of $1 / 3$ and 5/6"; this answer was accepted as an example of the not a problem category as the pre-service elementary teacher only rephrased the addition operation into words.

\section{The Error Types in the Problems Posed for the Addition of Fractions}

To determine the error types in the posed problems, first of all, problems with error(s) were identified. The frequencies of these errors are given below:

Table 3

The distribution of answers given to the last question of the PPT

\begin{tabular}{lllll}
\hline & Errorless & With Error & Not a Problem & Unable to Pose \\
\hline Write a story problem & & & & \\
for $\frac{1}{3}+\frac{5}{6}=?$ & 15 & 59 & 1 & 8 \\
\hline
\end{tabular}

As can be seen from the table, while only 15 of 83 pre-service elementary teachers successfully posed a problem, 59 pre-service elementary teachers posed problems with at least one error. When these errors in their posed problems were examined, nearly all of the types of errors mentioned in the methodology part of this paper were identified for the addition of fractions. The distribution of these error types are presented in the following table.

Table 4

The distribution of error types for the last question of the PPT

\begin{tabular}{|c|c|c|c|c|c|c|c|c|}
\hline & AE1 & AE2 & AE3 & AE4 & AE5 & AE6 & AE7 & AE8 \\
\hline Write a stor & & & & & & & & \\
\hline$\frac{1}{3}+\frac{5}{6}=?$ & 4 & 3 & 22 & 0 & 0 & 37 & 2 & 2 \\
\hline
\end{tabular}

Table 4 shows that 70 errors were identified in 59 posed problems containing at least one error. Furthermore, while AE3 and AE6 were the most common errors, AE1, AE2, 
AE7, and AE8 were rare. AE3 refers specifically to cases in which a pre-service elementary teacher attributes natural number meaning to the result of the addition of fractions. For example, a problem posed by one of the pre-service elementary teacher for $1 / 3+5 / 6=$ ? is: "A banana cake was divided into 3 equal pieces and 1 of them was eaten by Ayse. Another same sized strawberry cake was divided into 6 equal pieces and 5 of them were eaten by Ali. How many pieces did Ali and Ayse eat all together?"

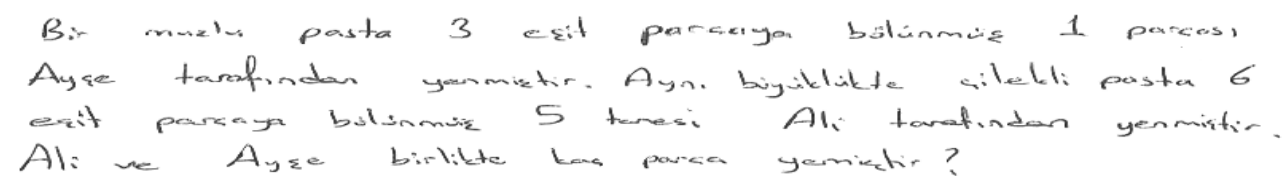

Figure 3

A problem with AE3

Another example of the error type (AE3) was given by PT23:

"Cengiz and Timur bought two pizzas of the same size. Cengiz cut one pizza into three slices of equal size and ate 1 of these slices. Timur cut the second pizza into six slices of equal size and ate five of these slices. How many slices were eaten by Cengiz and Timur in total?"

$$
\begin{aligned}
& \text { Cengiz be Tipmon agni bogoklokte iki pizzo dmishos cenglz bir pizzayi }
\end{aligned}
$$

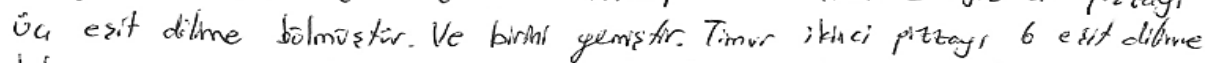

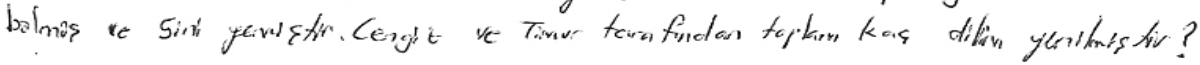

Figure 4

Another problem with AE3

As can be understood from the above problems, since the pre-service elementary teachers attributed the natural number meaning to the result of these operations by asking "how many pieces" or "how many slices", there is an AE3 error type in their posed problems.

According to the table, most of the pre-service elementary teachers failed in establishing part-whole relationship in their posed problems, which resulted in the error type AE6. This type of error refers to the problems in which the result of the operation is greater than a whole. For example, for the operation of $1 / 3+5 / 6=$ ?, a problem was posed as follows: "While Ali ate 1/3 of a rectangular cake, Elif ate $5 / 6$ of the cake. What fraction of the cake did they eat together?"

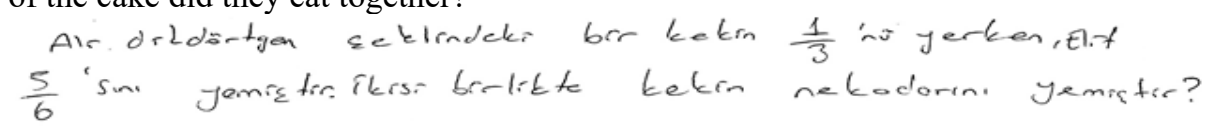

Figure 5

A problem with AE6

The following is another example of a problem that reflects how a pre-service elementary teacher did not consider the result of the operation required to solve his/her problem: "Ayse spent of $1 / 3$ of her money to buy a sweatshirt. She then spent $5 / 6$ of her money to buy a pair of jeans. What fraction of the money did Ayse spend to buy a sweatshirt and jeans?" 


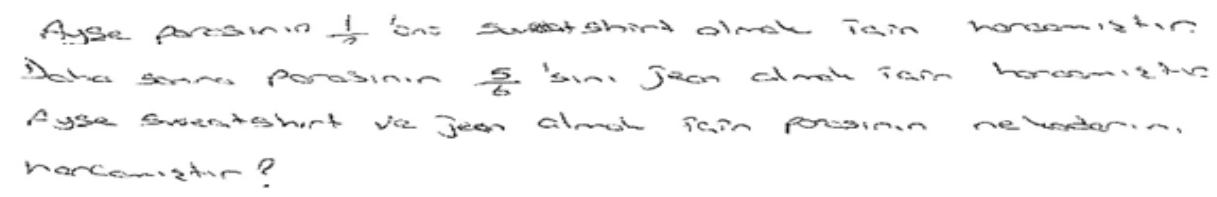

Figure 6

Another problem with AE6

As can be understood from the problem statements, the pre-service elementary teachers did not check whether their answers will be greater than one or not.

Other errors made by the pre-service elementary teachers for $1 / 3+5 / 6=$ ? fall under the error types of AE1, AE2, AE7, and AE8, which were rarer than the error types AE3 and AE6 mentioned above. The error type AE1 refers to the problems that express the added second fraction over the remainder of whole. The problem posed by the pre-service elementary teacher PT44 shows an example of this error: "Zeynep ate $1 / 3$ of her nuts and gave $5 / 6$ of her remaining nuts to her brother to eat. What fraction of nuts do they eat in total?" In the posed problem, as PT44 uses the word "remaining" and expresses the second fraction $(5 / 6)$ over the remainder of whole, $2 / 3$, the operation for her problem should be $1 / 3+(2 / 3 \times 5 / 6)=$ ?. In the above problem, PT44 also fails to express the operation in the question root, which is an example of another type of error, AE2.

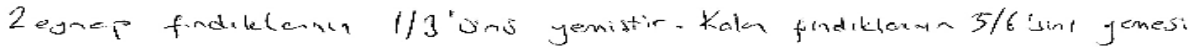

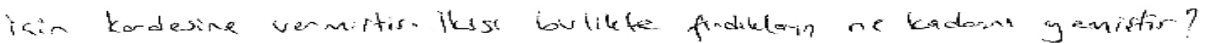

Figure 7

A problem with AE2

Another example of this error type was employed by PT79 in his problem as follows: "Fatma ate $1 / 3$ of a cake in the morning. In the evening, Ayse ate 5/6 of the cake. What is the fraction of the remaining cake?"

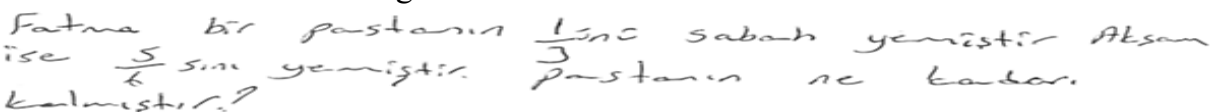

Figure 8

Another problem with AE2

Two of the pre-service elementary teachers had a difficulty resulting from the error type AE7. This error type refers to the problems in which the information given in the posed problem and the question asked in the posed problem are not relevant to each other. Specifically, one of the pre-service elementary teachers who employed the error type AE7 posed "While Seda ate 5/6 of a pizza, Hatice ate 1/3 of the same cake. What fraction of the cake was eaten by Seda and Hatice?"

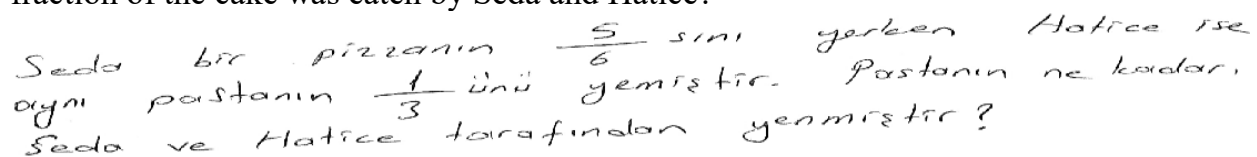

Figure 9

A problem with AE7 
As it is clear from the problem statement, the pre-service elementary teacher had used the word "pizza" to express a whole at the beginning of her problem. Then, she used the word "cake" instead of the pizza.

Furthermore, two of the pre-service elementary teachers could not pose an appropriate problem for $1 / 3+5 / 6=$ ? as they had difficulties resulting from the another type of error, AE8. AE8 refers to cases in which a pre-service elementary teacher attributes a value to the whole. One of the pre-service elementary teachers who committed the error AE8 posed a problem as follows: "Elif had two baskets. While one of these baskets had 8 apples, the other one had 4 peaches. Elif sold $1 / 3$ of apples and $5 / 6$ of peaches in the bazaar. How many fruits in total did Elif sell in the bazaar?"

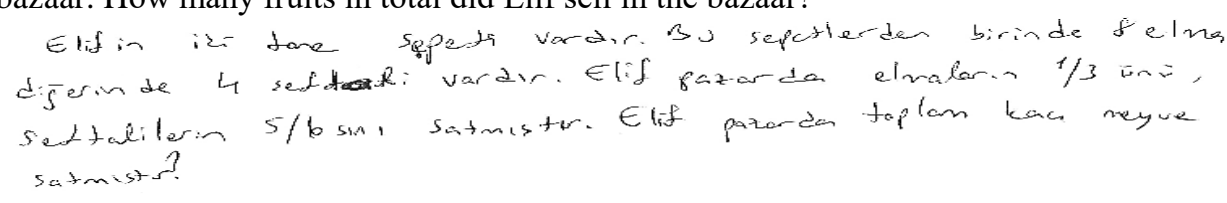

Figure 10

A problem with AE8

\section{DISCUSSION AND CONCLUSION}

This study aimed to identify the meanings focused on in pre-service elementary teachers' posed problems for the addition of fractions and to determine the types of errors made in these problems. For the last question in the PPT, 72 out of 83 pre-service elementary teachers posed a story problem for the given algorithmic expression. Considering the first question, the meanings, most of the pre-service elementary teachers preferred to pose a problem focusing on the part-part-whole meaning rather than the joining meaning of the addition of fractions. This finding is interesting as posing a partpart-whole problem is more difficult than posing a join problem (Jung, Kloosterman, \& McMullen, 2007). This finding raises the question of whether or not pre-service elementary teachers are aware of the meaning that they incorporated into their problems. Therefore, another study can also examine whether pre-service elementary teachers are able to identify the meanings that they focused on in their own posed problems. Being able to identify these meaning is important to know what kind of solutions can be provided by students and where the error is and what can be the next step in their solutions (Jung et al., 2007).

For the second question of the study, although the pre-service elementary teachers were able to pose problems focusing on the part-part-whole or joining meanings of the addition operation, most of the posed problems had at least one error. Therefore, it can be concluded that pre-service elementary teachers have difficulties in posing appropriate problems for the addition of fractions similar to the division of fractions (Isik \& Kar, 2012). Further studies can be conducted to examine whether these difficulties extend to other operations of fractions. The errors made in these problems showed that the preservice teachers had difficulties in six error types (AE1, AE2, AE3, AE6, AE7, and AE8) when posing problems for the addition of fractions. The most common of these errors was error type AE6 (37 errors), which represents the failure of the pre-service 
elementary teachers to establish part-whole relationship. This error type (AE6) is important as teachers help their students understand the connections between natural numbers and fractions by establishing part-whole relationship (Amato, 2005). Otherwise, pre-service elementary teachers who failed to establish part-whole relationship may not provide appropriate activities throughout the instruction and may not help their students see the fractions as numbers. So, despite being able to solve the algorithmic expression procedurally, the pre-service teachers did not check whether their problems were meaningful or not. Although the findings of this study cannot be generalized as the findings are based on the data gathered from a small sample of preservice elementary teachers, the findings provide an insight into pre-service elementary teachers' difficulties related to the addition of fractions. Furthermore, these findings extend the related literature as pre-service elementary teachers' difficulties are not specific to the division of fractions (Isik \& Kar, 2012; Redmond \& Utley, 2007; Rizvi, 2004; Toluk-Ucar, 2009). Further studies can be conducted to examine the reasons of the difficulties encountered during problem posing activities related to the fractions.

Teacher educators working with pre-service elementary teachers can organize their courses to address the difficulties that generate errors made in the problem posing activities. Addressing these difficulties may help pre-service elementary teachers know how to overcome their students' difficulties related to the problem posing. Therefore, providing pre-service elementary teachers with problem posing activities may increase their awareness of its importance and improve their abilities to pose appropriate problems. By means of these courses, pre-service elementary teachers would know how to incorporate problem posing activities into their future classrooms. During these activities, pre-service elementary teachers can understand that a story problem's correctness as well as its structure need to be considered when they are trying to pose it. This understanding may help them realize that applying procedures or rules correctly is not enough to pose an appropriate problem for an algorithmic expression.

\section{REFERENCES}

Amato, S. A. (2005). Developing students' understanding of the concept of fractions as numbers. In Chick, H. L. \& Vincent, J. L. (Eds.). Proceedings of the 29th Conference of the International Group for the Psychology of Mathematics Education 2, 49-56. Melbourne: PME.

Beckmann, S. (2005). Mathematics for elementary teachers. Boston: Addison Wesley.

Bonotto, C. (2009). Working towards teaching realistic mathematical modeling and problem posing in Italian classrooms. In L. Verschaffcl, B. Greer, W. Van Dooren, \& S. Mukhopadhyay (Eds.), Words and worlds: Modelling verbal descriptions of situations (pp. 297-313). Rotterdam: Sense Publishers.

Bonotto, C. (2013). Artifacts as Sources for Problem-Posing Activities. Educational Studies in Mathematics, 83(1), 37-55. 
Bottge, B. A., Ma, X., Gassaway, L., Toland, M., Butler, M., \& Cho, S. J. (2014). Effects of Blended Instructional Models on Math Performance. Exceptional Children, $80,423-437$.

Brown, S. I. \& Walter, M. I. (1993). Problem posing: Reflection and application. Hilsdele, NJ: Erlbaum Associates.

Brown, S. I. \& Walter, M. I. (2005). The art of problem posing. Mahwah, NJ: Lawrence Erlbaum Associates.

Cathcart, W. G., Pothier, V. M., Vance, T. H., \& Bezuk, N. S. (2003). Learning mathematics in elementary and middle schools. (3th Ed.) River, N.J: Merrill/Prentice Hall.

Charalambous, C. Y. \& Pitta-Pantazi, D. (2007). Drawing a Theoretical Model to Study Students' Understanding of Fractions. Educational Studies in Mathematics, 64, 293-316.

Christou, C., Mousoulides, N., Pittalis, M., Pitta-Pantazi, D., \& Sriraman, B. (2005). An Empirical Taxonomy of Problem Posing Process. ZDM-The International Journal on Mathematics Education, 37(3), 149-158.

Conference Board of the Mathematical Sciences (CBMS) (2001). The mathematical education of teachers. Providence, RI and Washington, D.C.: American Mathematical Society and Mathematical Association of America.

Crespo, S. \& Sinclair, N. (2008). What Makes a Problem Mathematically Interesting? Inviting Prospective Teachers to Pose Better Problems. Journal of Mathematics Teacher Education, 11(5), 395-415.

Cunningham, R. (2004). Problem Posing: An Opportunity for Increasing Student Responsibility. Mathematics and Computer Education, 38(1), 83-89.

Davidson, A. (2012). Making It in America. Retrieved from https://www.theatlantic.com/magazine/archive/2012/01/making-it-in-america/308844/

Dubé, A. K. \& Robinson, K. M. (2010). Accounting for individual variability in inversion shortcut use. Learning and Individual Differences, 20(6), 687-693.

Isik, C. \& Kar, T. (2012). An Error Analysis in Division Problems in Fractions Posed by Pre- Service Elementary Mathematics Teachers. Educational Sciences: Theory \& Practice, 12(3), 2289-2309.

Isiksal M (2006). A study on pre-service elementary mathematics teachers' subject matter knowledge and pedagogical content knowledge regarding the multiplication and division of fractions. Unpublished doctoral dissertation, Middle East Technical University, Turkey.

Jung, M., Kloosterman, P., \& McMullen, M. B. (2007). Young Children's Intuition for Solving Problems in Mathematics. Young Children, 62(5), 50-57. 
Kilic, C. (2015). Analyzing Pre-Service Primary Teachers' Fraction Knowledge Structures Through Problem Posing. Eurasia Journal of Mathematics, Science \& Technology Education, 11(6), 1603-1619.

Kilpatrick, J. (1987). Problem formulating: where do good problems come from? In A. H. Schoenfeld (Ed.), Cognitive science and mathematics education, (pp. 123-147). Hillsdale, NJ: Lawrence Erlbaum Associates.

Kontorovich, I., Koichu, B., Leikin, R. \& Berman, A. (2012). An Exploratory Framework for Handling the Complexity of Mathematical Problem Posing in Small Groups. Journal of Mathematical Behavior, 31(1), 149-161.

Lamon, S. J. (2006). Teaching fractions and ratios for understanding: Essential content knowledge and instructional strategies for teachers. (2nd Ed.). Erlbaum, Mahwah, NJ.

Lamon, S. J. (2012). Teaching fractions and ratios for understanding: Essential content knowledge and instructional strategies. New York, NY: Taylor \& Francis Group.

Ministry of National Education [MoNE]. (2018). Mathematics program (Elementary and Middle School 1, 2, 3, 4, 5, 6, 7, and 8 Grades).. Ankara: Devlet Kitaplar1 Müdürlüğü.

Moseley, B.J. Okamoto, Y., \& Ishida, J. 2007. Comparing US and Japanese Elementary School Teachers' Facility for Linking Rational Number Representations. International journal of science \& mathematics education, 5, 165-185.

Moss, J. \& Case, T. (1999). Developing Children's Understanding of the Rational Numbers: A New Model and an Experimental Curriculum. Journal for Research in Mathematics Education, 30, 122-148.

National Council of Teachers of Mathematics. (1989). Curriculum and evaluation standards for school mathematics. Reston, VA: Author.

National Council of Teachers of Mathematics. (1991). Professional standards for teaching mathematics. Reston, VA: National Council of Teachers of Mathematics.

National Council of Teachers of Mathematics. (2000). Principles and Standards for School Mathematics. Reston, VA: Author.

National Mathematics Advisory Panel [NMAP]. (2008). The Final Report of the National Mathematics Advisory Panel). Retrieved from https://www2.ed.gov/about/bdscomm/list/mathpanel/report/final-report.pdf

Newton, K. J. (2008). An Extensive Analysis of Pre-Service Elementary Teachers' Knowledge of Fractions. American educational research journal, 45(4), 1080-1110.

Newton, K. J., Willard, C., \& Teufel, C. (2014). An Examination of the Ways that Students with Learning Disabilities Solve Fraction Computation Problems. The Elementary School Journal, 115, 1-21. 
Ni, Y. \& Zhou, Y.-D. (2005). Teaching and Learning Fraction and Rational Numbers: The Origins and Implications of Whole Number Bias. Educational Psychologist, 40, $27-52$.

Olson, J. C. \& Knott, L. (2013). When a problem is more than a teacher's question. Educational Studies in Mathematics, 83, 27-36. Petit, M. M., Laird, R. E., Marsden, E. L., \& Ebby, C. B. (2015). A focus on fractions: Bringing research to the classroom. Routledge.

Redmond, A. \& Utley, J. (2007). Prospective elementary teachers understanding of and attitudes towards the division of fractions. Paper presented at the Research Council on Mathematics Learning Annual Convention, Oklahoma City, OK

Rizvi, N. F. (2004). Prospective Teachers' Ability to Pose Word Problems. International Journal for Mathematics Teaching and Learning, 12, 1-22.

Rizvi, N. F. \& Lawson, M. J. (2007). Prospective Teachers' Knowledge: Concept of Division. International Educational Journal, 8(2), 377-392.

Siegler, R. S. \& Pyke, A. A. (2013). Developmental and Individual Differences in Understanding of Fractions. Developmental Psychology, 49, 1994 -2004.

Silver, E. A. (1994). On Mathematical Problem Posing. For the Learning of Mathematics, 14(1), 19-28.

Singer, F. M., Ellerton, N., \& Cai, J. (2013). Problem Posing Research in Mathematics Education: New Questions and Directions. Educational Studies in Mathematics, 83, 1-7.

Smith, J. P. (2002). The development of students' knowledge of fractions and ratios. In B. Litwiller \& G. Bright (Eds.), Making sense of fractions, ratios, and proportions. Reston, VA: National Council of Teachers of Mathematics.

Stoyanova, E. (1995). Developing a framework for research into students' problem posing in school mathematics. Paper presented at the 18th Annual Conference of the Mathematics Education Research Group of Australasia.

Stoyanova, E. (2003). Extending Students' Understanding of Mathematics via Problem Posing. The Australian Mathematics Teacher, 59(2), 32-40.

Tichá, M. \& Hošpesová, A. (2009). Problem posing and development of pedagogical content knowledge in pre-service teacher training. In (Eds.) Paper presented at the proceedings of CERME 6, Lyon, France. (pp. 1941-1950).

Toluk-Ucar, Z. (2009). Developing Pre-Service Teachers Understanding of Fractions through Problem Posing. Teaching and Teacher Education, 25(1), 166-175.

Van de Walle, J., Karp, K., \& Bay-Williams, J. M. (2016). Elementary and Middle School mathematics: Teaching Developmentally (9th Ed). New York, NY: Pearson Education, Inc.

Wu, H. (2008). Fractions, Decimals, and Rational Numbers. Retrieved from https://math.berkeley.edu/ wu/NMPfractions.pdf 